\title{
THE ARCHITECTURE OF STRATEGIC MARKETING AT THE CORPORATE AND FUNCTIONAL LEVELS OF A COMPANY
}

\author{
Natalya GURZHIY \\ Donetsk National University of Economics and Trade after M. Tugan-Baranovsky, Ukraine
}

\begin{abstract}
The article gives a treatment of the specificity of strategic marketing, the architecture of strategic marketing as a construction and logical combination of the platform and components of strategic marketing infrastructure at the corporate and functional level, which are used for the development and support of the strategic marketing system of a company.
\end{abstract}

\section{JEL CLASSIFICATION \& KEYWORDS}

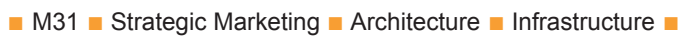
Platform $\backsim$ Components $\backsim$ Corporate Level $\backsim$ Functional Level Strategic Planning

\section{INTRODUCTION}

An important specificity of the current stage of market relations development in Ukraine is orientation of many domestic companies towards raising the competitiveness of their products. Marketing activity plays a key role in the process, in particular, the formation of a marketing strategy at a company. The realities of the economy show us that companies neglecting strategic marketing in their activity fail to stay competitive. Marketing, in the first turn, provides companies with a clear trajectory of actions. The value of strategic marketing is not only in its capacity to provide companies with a perfect market research and reveal opportunities, but in the ability to provide information to planning, production and sales departments which will allow creating the most efficient plans for the future with the aim of increasing competitiveness both on the domestic and foreign markets.

Representing a generalized model of the long-term actions plan, strategic marketing offers solutions to urgent questions of the present day: how to avoid imbalance among marketing activity, market demand and the company's finance, how to secure the company's constant growth, avoid crises inherent to the period of rapid growth and how to manage limited resources with maximum efficiency.

Strategic marketing represents the basis for a company's marketing policy which takes into account the interests of all participants of the market in the company's environment.

Strategic marketing rests on the analysis and forecast results of the existing environment conditions as well as on the consideration of the strengths and weaknesses of the company's own activity. Consequently, it secures and further develops the success achieved on the market, opens up new opportunities, creates and secures the company's long-term development perspective. There are different views on the definition of the concept of strategic marketing. The analysis of different viewpoints on the nature of strategic marketing has revealed that this phenomenon possesses specificity when compared with the marketing methodology developed earlier.

Strategic marketing performs the following functions:
1. Treats the consumer not as a passive object of activity on the part of the producer, but as an active and equal market participant with a long-term program of his actions.

2. Defines the producer as an active participant of the market economy the main objective of which is further growth through satisfying the requirements of other economic subjects interested in his activity. Profit is viewed as a tool for achieving the tasks set for the company.

3. Researches, generalizes and analyses the interaction process between the consumer and the producer from the standpoint of optimization of their relations which lead to a better satisfaction of the producer's needs in financial resources raised from the sale of goods and services, and the consumer's need in benefits which are necessary for the satisfaction of the consumer's requirements.

4. Considers the interaction between the producer and the consumer not as a competition (the economic and mathematical model of such competition is represented as a game between two parties with opposite interests) but rather as a cooperation with regular information exchange with the prospect for a long-term co-existence, i.e. symbiosis.

5. Introduces new content to the concept of market information utilizing new methods of data gathering and analysis, offers new application of the concept for making forecasts of changes in the demand and consumer behavior.

6. Offers a new (dynamic) concept for the research of consumer behavior instead of the static one which allows forecasting the demand without taking into the account psychological determinants in behavior motivation. The dynamic concept of consumer behavior research pays main attention to the research of decision-making processes which consumers perform, consumers' purchasing strategy development on the basis of the consumer psychology and the specifics of consumer psychology on the basis of psychographic segmentation criteria.

7. Introduces the concept of "multi-attribute" goods which provides basis for market research and market strategy development for different groups of prospective consumers. "Multi-attribute" goods may be considered as "a materially substantial" nucleus surrounded by certain "information field" which characterizes the diversity of technical and aesthetic embodiment of the goods, as well as various additional potential services that accompany the product on its way to the end user. The main attributes (benefits) of goods may be of different value to different consumers. For example, a printer may have such attributes as efficiency, print quality, noiselessness, print speed, design etc. The strengthening of separate attributes of goods requires fine-tuning of marketing tools in order to influence the prospective customers. 
8. Targets marketing activity not only at the consumers' interests but pursues the benefit of all economic subjects interested in the activity of a certain producer.

In its generalized meaning "architecture" is a manifestation of construction logic inherent to the system (for example a building or technological or information system), a general plan or concept used for its creation and, on the other hand "an abstract description of a system, its structure, components and their interrelations" (Grigorjev, Kudryavtsev, Gorelyk).

According to the definition of Gartner, architecture is (Gartner, 2002):

1. A general plan or a concept used for the creation of a system such as a building or an information system or "an abstract description of a system, its structure, components and their interrelations";

2. A set of guidelines, concepts, rules, schemes, interfaces and their standards used in the creation of an integral information system of a company.

Enterprise architecture determines the overall structure and function of such system within the company in general (including partners and other organizations which form the so-called "expanded company") and supports the common framework model, standards and guidelines for the architecture of separate projects level.

The Global Enterprise Architecture Organization gives the following definition of enterprise architecture: enterprise architecture is the composition of enterprise components, and their relationships with the external environment, and the guiding principles for the requirement (analysis), design, and evolution of an enterprise. At different generalization levels it provides a unique set of models, principles, administration and policies which are used for the creation, development and securing the appropriateness of the system at the scale and in the context of an enterprise in general.

P. Kotler introduces the following elements to the concept of marketing architecture: marketing environment, the global market, consumer markets and consumer behavior consumer behavior on the market of companies, marketing information and market research (Kotler, 1999).

The architecture of strategic marketing is viewed as a construction and logical combination of the platform and components of strategic marketing at the corporate, functional and process levels which are used for the development and maintenance of a company's strategic marketing.

The architecture of strategic marketing stipulates its objective, vital functions, active components and key processes. Also, it shapes the nature of their relations. The architecture of strategic marketing consists of a set of separate but mutually interconnected platforms which create the total multi-dimensional modular structure. Each platform reflects a certain element (aspect) of the system together with its specifics and intrinsic criteria as well as efficiency parameters.

Let us consider separate levels of the architecture of strategic marketing in more detail.

The platform of architecture at the level of enterprise is represented by the strategic enterprise identification.

The components of architecture at the enterprise level are represented by the strategic mission of a company, objectives and the overall strategy of the company's development. (Figure 1.)

www.journals.cz/
Figure 1. The characteristics of infrastructure as a component of strategic marketing architecture

The architecture of the enterprise level of strategic marketing

\begin{tabular}{l|l} 
Infrastructure & Platform: strategic identification of an enterprise.
\end{tabular}

Elements: the company's strategic mission,

objectives, overall strategy of the company's development.

The architecture of the functional level of strategic marketing

\begin{tabular}{|l|l|l}
\hline Infrastructure & Platform: the system of strategic marketing,
\end{tabular} marketing audit, strategic planning, strategic organization, strategic control.

Elements: market environment research, whole companies, strategic areas of business activity, marketing strategy, implementation of tactics.

Source: Author

The precise mission of a company in the market environment should be visible from the very beginning. The mission of a company (corporate mission, business mission) is a generalized long-term aim of a company, which manifests the company's reason for existence. The mission may change in line with the growth of the company, expansion of product range and the emergence of new markets. A company's mission must be formulated in a detailed list of auxiliary missions and tasks for each structural division and each administrator. An appropriate strategy is required for the solution of these tasks.

The overall (general) strategy of company development is connected with the activity of a company in general, utilization of all resources and orientation towards achieving the main objective.

The architecture of the functional level of strategic marketing includes the following elements:

1. An architecture platform (a system of strategic marketing which includes marketing audit, strategic planning, strategic organization and strategic control).

2. The elements of architecture of the functional level which are the research of the market environment, entire companies, areas of business activity, marketing strategy and the implementation of tactics.

Marketing audit is a systematized and impartial survey of the environment, objectives and strategy of a company in the field of marketing for revealing the opportunities, problems and devising a plan of development, which enables to improve the company's position with the help of marketing (Sovremennyj marketing, 1999).

The objective of marketing audit is specification of the marketing aim and the company's marketing strategy.

The task of marketing audit is to provide the most efficient ways for achieving the aims of the company.

Audit of marketing may be used both for operating enterprises and the existing fields of business and for new projects as well. Marketing audit may be held at the level of the entire company and at the levels of a structural division, investment project or commercial offer (Sovremennyj marketing, 1999)

For control and analysis of important aspects of the company's activity the management may choose the following organizational form of audit: internal audit (held by the owner depending on the necessity, aim and strategy of marketing activity management), external audit (held by an audit company under the contract with the customers). External marketing audit mostly targets the research and analysis of the micro and macro environment. The objects of a detailed survey in the micro environment are markets 
consumers, competitors, distribution channels, suppliers, auxiliary and marketing companies, the public. Internal marketing audit targets the research and analysis of the marketing strategy, organization of marketing, marketing system, function and marketing capacity of the company. The following factors determine marketing audit (Dadyo, 2006):

1. Important marketing resources of the company and the list of critical marketing requirements of the company along with the indication of satisfactory and unsatisfactory performed tasks.

2. Information on the marketing position of the company in relation to the consumers, competitors, suppliers and other participants.

3. An assessment of the current marketing activity.

4. The list of marketing resources and competencies which the company should procure.

5. Recommendations concerning the future policy of the company on the market from the standpoint of marketing and expected results.

The basis of any planning within the framework of a company is strategic planning. P. Kotler defines planning as an administrative process of creating and maintaining of strategic accordance among the mission of the company, opportunities and chances in the field of marketing. The main definitions of the concept of strategic marketing offered by different researchers are listed in the table 1 .

Strategic planning is a modern modification of internal planning at a company. The objective of strategic planning is to improve the response of the company to the market dynamics and competitors" behavior. (Table 1.)

Table 1. Definitions of the concept of strategic marketing

\begin{tabular}{|l|l|}
\hline Doyle P. & $\begin{array}{l}\text { Strategic market planning may be defined as a } \\
\text { process of development managing and retaining } \\
\text { the accordance of the strategy and company } \\
\text { organization with the changes in the } \\
\text { environment. }\end{array}$ \\
\hline McDonald M. & $\begin{array}{l}\text { It is a process of setting long-term aims and } \\
\text { strategy formulation for the whole company or } \\
\text { for its departments by means of comparing the } \\
\text { resources available and potential opportunities. }\end{array}$ \\
\hline Ansoff I. & $\begin{array}{l}\text { Strategic planning is a process of defining a } \\
\text { company's main objective, resources essential } \\
\text { for its achievement and the policy directed at } \\
\text { obtaining and utilization of the necessary } \\
\text { resources. }\end{array}$ \\
\hline Cleeland W. & $\begin{array}{l}\text { Strategic planning is a management process } \\
\text { with the purpose of achieving the aim of a } \\
\text { company through managing the interaction } \\
\text { between the company and the environment. }\end{array}$ \\
\hline Hentse I. & $\begin{array}{l}\text { Strategic planning is a set of procedures and } \\
\text { decisions with the help of which an enterprise } \\
\text { strategy is developed which secures the } \\
\text { achievement of the company's aims. }\end{array}$ \\
\hline
\end{tabular}

Source: Author

The core of strategic planning is an analysis of internal capacities, external competitive forces and a search for the ways of using external opportunities taking into account the company's specifics.

From the standpoint of marketing a strategic plan demonstrates what marketing actions should be taken, why they are required, where they should take place and how they will be accomplished. A strategic plan also defines the current position of the company, the company's future direction and resources distribution.

The process of strategic planning may consist of four mutually connected stages:
1. Definition of a company's aim (launching a new product onto the market, cessation of sales of old products and services, winning a new group of consumers, upsizing or downsizing through an acquisition or sale).

2. Creation of strategic areas of business activity at a company with a group of products or a certain product department under control with concentration on a certain market. Appointment of a manager responsible for uniting all functions into a strategy.

3. Definition of the aim of marketing in quantitative indexes and qualitative characteristics.

4. Situational analysis which defines marketing opportunities and problems which the company may encounter.

5. Development of a marketing strategy.

6. Implementation of tactics-real actions targeting the realization of the chosen marketing strategy.

7. Results monitoring-comparing the planned parameters with real achievements over a definite period of time.

The modern concept of strategic marketing presumes the use of an effective methodology tool for strategic segmentation and definition of strategic areas of business activity when devising a company's strategy.

The strategic control of marketing means a regular check-up of the correspondence of the aim, the initial strategic objective and the company's program to the requirements of the existing and forecasted marketing and market opportunities.

The objective of strategic marketing control is the awareness of how the company takes advantage of the existing opportunities and how efficiently they do so. Along with it, the aim is to reveal the areas where problems and new opportunities exist and to develop recommendations concerning the formation of a plan of improving the efficiency of marketing activity.

The task of strategic control is to check the following:

1. The correctness of choosing the aim for the company and the aim of marketing activity.

2. Correspondence of the chosen strategy to the changing environment.

3. Utilization by the company of its potential capacity in respect of sales markets, target consumer groups, the goods and distribution channels.

\section{REFERENCES}

1. Ansoff, I., 1989. Strategicheskoye upravleniye (transl. from English) E.L.Leontyeva, M.

2. Cleeland, W., 2000. Strategicheskoye planirovaniye v organizatsiyah, $M$.

3. Dadyo, Y., 2006. "Marketingovy audit - zasib pidvushenna konkurentozdatnosti pidpryjemstv", Marketing in Ukrajini, No2, pp.47-51.

4. Doyle, P., 1999. Menedjment: strategiya i taktika, S.Pb., 560 pp.

5. Gartner, 2002. What is an Architecture Style? http://www.INTUIT.ru.

6. Grigorjev, L.U., Kudryavtsev, D.V., Gorelyk, S.L. "Korporativnaya arhitectura i yeyo sostavlaushiy" http://bigc.ru/theory/innovations/innovations.php.

7. Hentse, I., 1989. "Osnovnyje tseli strategycheskogo menedjementa", Problemy teoriy I practiki upravleniya, No12, p.96.

8. McDonald, M., 2000. Strategicheskoye planirovaniye marketinga, S.Pb., $267 \mathrm{pp}$

9. Sovremennyj marketing. Nastolnaya kniga po issledovaniu rinka, 1999. Uchebn. posobiye / B.E. Chrytsky, I.V. Korneeva. - 2-e izd., perer. i dop. - M.: Financy I statistica, 528 pp.

10. Kotler, Ph., 1999. Marketing, management, analiz, planirovaniye, vnedreniye, control, S.Pb., $896 \mathrm{pp}$. 